\title{
Monomers from Resin-Based Materials: Risk Assessment In Dental Medicine
}

Research Article

Maha H. DAOU*

Associate Professor, School of Dental Medicine, Saint Joseph University Beirut, Lebanon.

\section{Introduction}

Resin composites, which are commonly used in restorative dentistry, consist of a cross-linked polymer matrix and fillers at 60 to $80 \%$ by weight. The resins used are generally made of very large molecules, like bisphenol A glycidyl methacrylate (BIS-GMA), a highly viscous component. In view of reducing the composite's viscosity and improving its handling properties, other components are usually added, such as the diluent tri-ethylene glycoldimethacrylate (TEGDMA). The mineral fillers should be of very small size and treated on their surface by a silane coupling agent, which is added and linked to the particles in order to achieve strong bonding with the resin during polymerization.

Resin-based composites present high failure rates [1]. Concerns over their reduced durability, prevalence of secondary caries from resin-based dental materials have come to the fore [2]. In addition, patients express their concerns with respect to the safety of resin-based materials that might release chemicals like bisphenol A (BPA), TEGDMA, and hydroxyethyl methacrylate (HEMA) [3].

Bisphenol A (BPA), an organic compound, is the common name for 2, 2-Bis (4-hydroxyphenyl) propane, produced by the reaction of two phenols with one acetone catalyzed by a cationexchange resin. BPA is a xenoestrogen, a known endocrine disruptor presenting estrogenic activity similar to that of normal estrogens following their binding to human estrogenic receptors [4, 5]. Human exposure to BPA can be detrimental to health due to its numerous adverse effects [6]. BPA release from dental composite materials has been extensively discussed in the literature [7].

As to BISGMA and TEGDMA, it degrade in the oral cavity and generate bishydroxy-propoxyphenyl-propane (BisHPPP), methacrylic acid (MA), and triethylene glycol (TEG), respectively [8] [9].

The aim of this paper is to evaluate the risk arising from the elu- tion of co-monomers, particularly TEGDMA, which is present in most composite resins and its degradation by-products, and of Bisphenol A, which could probably be released under very particular conditions.

\section{Tri-Ethylene-Glycol-Dimethacrylate (TEGDMA)}

Tri-ethylene glycol-dimethacrylate (TEGDMA), with a molecular weight (MW) of 286, is a long molecule terminated by two functional methacrylate groups, like Bis-GMA, the backbone molecule of composites. The molecule part between the two methacrylate groups, however, is linear, as compared to Bis-GMA (MW 512), therefore, it does not possess the high viscosity specific to BisGMA. Here lies the reason why TEGDMA is used as a diluent for Bis-GMA, improving the handling of the composite resin both during manufacturing, improvement of the coat of the filler particles, and during clinical use by the dentist.

\section{Bisphenol A (BPA)}

Pure BPA does not exist as a component in composites, adhesives, or sealants, but it is used in the synthesis of the main backbone molecule of composite resins, namely bisphenol A-diglycidyl methacrylate (Bis-GMA), in monomers such as bisphenol A-diglycidylether (BADGE), or bisphenol A-dimethacrylate (BisDMA), which is used in a number of adhesives and sealants [10].

\section{TEGDMA and BPA in Dental Biomaterials}

TEGDMA is a linear co-monomer that terminates with two functional methacrylate groups identical to those terminating bisglycidyl methacrylate [Bis-GMA]. During polymerization, acrylic bonds are created with Bis-GMA as well as with other TEGDMA molecules and with the mineral filler particles by means of a coupling agent grafted on these filler particles, which also has a terminal functional methacrylate group. This formed tridimensional network is characterized by high mechanical and chemical resist-

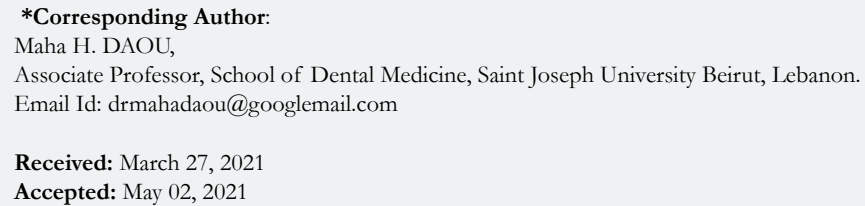

Copyright: Maha H. DAOU ${ }^{\circ} 2021$. This is an open-access article distributed under the terms of the Creative Commons Attribution License, which permits unrestricted use, distribution and reproduction in any medium, provided the original author and source are credited. 
ance; the acrylic bonds thus formed are highly stable in the oral environment. Monomer and comonomer polymerization is never complete. The conversion rate, i.e. the proportion of polymerized molecules compared to the initial amount of unpolymerized molecules, is estimated to vary between 30 and $80 \%$, depending on the resins. Therefore, free monomers and co-monomers are always present in composite resins, which could conceivably be eluted [11].

Since TEGDMA can virtually never result from the polymerized matrix degradation, it would hence be logical to conclude that the eluted TEGDMA stems from unpolymerized molecules. The amount of eluted TEGDMA was shown [12,13] to decrease when a composite is exposed to a longer light irradiation time, i.e. when polymerization increases and free TEGDMA content decreases [14-16].

The composition of a composite resin, an adhesive or a sealant, does not include bisphenol A (BPA) as an ingredient, yet the latter was unintentionally introduced in some of them. It has been found as an impurity in bisphenol A-diglycidylether (BADGE) and in bisphenol A dimethacrylate (Bis-DMA), both used in a number of sealant preparations, from some base chemical manufacturers [17].

\section{TEGDMA and BPA Release from Dental Bioma- terials}

Monomers can be released from restorative materials. According to Goldberg, substances are released first during the monomerpolymer conversion, which occurs in the first hours subsequent to polymerization and, secondly, as the release of substances that can happen because of erosion and degradation over time. The free monomer initial release might occur during the monomerpolymer conversion, whereas the long-term release of leachable substances is produced by erosion and degradation over time [18].

A study by Durner et al. (2009) showed that 64 different compounds are released into aqueous or organic solvents. TEGDMA was released at a considerable concentration $(0.04-2.3 \% \mathrm{wt})$, whereas Bis-GMA, urethane dimethacrylate (UDMA), 2-hydroxyethyl methacrylate (HEMA), hexanedioldimethacrylate (HDDMA), ethylene glycol dimethacrylate (EGDMA), and diethylene glycol dimethacrylate (DEGDMA) with minor concentrations [19]. Van Landuyt et al. (2011) demonstrated that more than 30 different compounds could be extracted from polymerized dental composites, and among those, one could detect major monomers, co-monomers, various additives, and reaction products [20].

Monomer release continues over time, lasting up to 30 days [21] and even for up to 12 months subsequent to polymerization [13]. In a study conducted by Putzeys et al., the long-term elution of a wide array of compounds from resin-based dental composites, including BisEMA3, BisEMA6, BisEMA10, Bis-GMA, camphorquinone (CQ), HEMA, TCD-DI-HEA, TEGDMA, and UDMA, were quantified. The aforesaid tested composites continued to release small quantities of monomers over time [22] with TEGDMA presenting a faster elution rate as compared to the other monomers [23].

Rothmund et al. (2017) investigated the effect of layer thick- ness on the elution of components from bulk-fill composites. They identified 11 elutable substances, with TEGDMA showing an elution increase at a higher layer thickness [24]. In a 2018 study, TEGDMA showed the highest elution level compared to the other monomers [25]. A total of 12 substances were detected from the investigated composite eluates, five of which were methacrylates, namely TEGDMA, HEMA, hydroxypropyl methacrylate (HPMA), EGDMA, and trimethylolpropane trimethacrylate (TMPTMA) [26]. BisGMA, UDMA, TEGDMA, and HEMA were detected from composite resins after incubation in 3 different solutions. Lagoska $\mathrm{R}$ et al. [27]. «The highest amount of released residual monomer from all groups was TEGDMA. » [28].

\section{Toxicology of TEGDMA and BPA}

Numerous studies have clearly demonstrated the release of the free comonomer TEGDMA from polymerized composite resins. At this point, the risk that this component carries on cells and on the organism, i.e. its toxicity, must be scrutinized. TEGDMA's cytotoxicity is mainly associated to the short-term release of free monomers during the monomer-polymer conversion process, with at least $5 \%$ remaining unreacted. However, this might be sufficient in order to contribute to permeability and the thickness of residual dentin [30]. The composite resin surface exposed to oxygen during the curing process produces a non-polymerized surface layer rich in formaldehyde, which in itself constitutes an additional factor of cell toxicity [31].

HEMA and TEGDMA were the only ones to boost the diffusion ability through dentin into the pulp at significantly high concentrations in the millimolar range. When the remaining dentin thickness decreases, especially below $1 \mathrm{~mm}$ or following a treatment involving acid etching, diffusion tends to increase [32].

There are three main routes of systemic intake from chemical substances released by resin-based restorations [14]: via the gastrointestinal tract, by diffusion to the pulpal tissues, and directly to the oral mucosa, all of which are of greater relevance to the patient [33]. Regarding the uptake of volatile components in the lungs, it is of particular importance for dental practitioners and dental personnel [34].

TEGDMA's cytotoxicity may be of great clinical interest. Numerous resin-based materials release substantial amounts of this relatively hydrophilic monomer. Additionally, this substance may considerably contribute to the incidence of adverse local and systemic effects [35].

\section{TEGDMA}

Time- and concentration-dependent cytotoxicity in various cell lines are prominent features of TEGDMA. At lower concentrations, the major type of TEGDMA-induced cell death was apoptosis, i.e. programmed cell death, whereas necrosis was more manifest at higher concentrations $[36,37]$. TEGDMA has the potential to affect the physiological differentiation of dental pulp fibroblasts into odontoblasts and their normal mineralization procedure at very low concentrations [38]. TEGDMA is also known to cause deoxyribonucleic acid (DNA) strand breakage [39, 40].

Since TEGDMA is rapidly taken up in the gastric tract, it can eas- 
ily disseminate and spread throughout the body (41), and presents well-documented mutagenic effects $[42,43]$. Moreover, TEGDMA leads to severe toxicity and should, therefore, be completely avoided in new formulations [10].

When BISGMA and TEGDMA degrade in the oral cavity, it generates bishydroxy-propoxy- phenyl propane (BISHPPP), methacrylic acid (MA), and triethylene glycol (TEG), respectively. These by-products adversely affect host cells and function of oral microorganisms [44-46].

Furthermore, TEGDMA stimulates the growth and proliferation of caries-relevant bacteria, such as Streptococcus sobrinus, Streptococcus mutans, and Lactobacillus acidophilus, thereby contributing to pulpal inflammation and secondary caries formation [44]. Reichl in 2009 [47] first showed that TEGDMA tends to degrade into triethyleneglycol and methacrylic acid, and second that the various methacrylate-related diseases clearly boast a tendency towards increasing frequency. Thus, dental professionals garner about $45 \%$ of all allergies due to methacrylates, with the dental personnel being more susceptible (5\% of cases in Scandinavia, 2007 values) than the dentists $(4 \%)$ and the patients themselves $(2.3 \%)$. A large number of Lebanese dentists suffer from hand eczema, a contact allergy [48].

A wide array of studies have been dedicated to TEGDMA's stability and its potential action on different cell types. Seiss shows that TEGDMA and HEMA can degrade under the effect of enzymes such as esterase, with the risk of forming lipophilic intermediary products, which can thus accumulate in adipose tissues [49]. In his thorough review of the chemical and biological interactions of TEGDMA, Geurtsen had already determined in 2001 that this substance has the potential to interact with various cell structures and, therefore, presents a high toxicity [50].

Later, the work of Emmler [51] on the toxicity of TEGDMA in pulmonary cells, that of Gregson [52] on human pulpal and gingival fibroblasts, and that of Imazato [53] on osteoblast-type cells, all corroborated the cytotoxicity of TEGDMA. The different origins of these three studies - Germany, the United States of America, and Japan - serve as a solid proof of the magnitude and actuality of this problem.

With respect to BPA, Tillet raised the issue of the controversial swirling around its influence on health, particularly at the endocrine level, and on the risks inherent in its use when it comes to the development of a number of diseases like diabetes as well as cardiac and liver pathologies [54].

Sealants can release high amounts of TEGDMA and CQ. Because of the use of sealers in prophylactic dentistry, it is deemed true that allergic reactions to TEGDMA and CQ can exist and may be activated. A detailed allergological anamnesis should be carried out prior to material insertion in order to avoid potential reactions or triggering thereof [55].

BPA is presumably hazardous to human health [56]. The amounts of BPA leached from resin- based restorative materials were relatively low and most likely represent a very small contribution to the total BPA exposure [57]. However, it is noteworthy to mention in this context that $93 \%$ of Americans aged over 6 years have residues of BPA in their urine. This BPA tends to accumulate in adipose tissues and surely stems from a non-food source. Dental restorative materials like composite resins and sealants are a possible source of BPA, among others. Already in 1999, ArenholtBindslev et al. [58] showed that the sealant DELTON® (containing Bis- DMA) released BPA in saliva during sealant application, and that BPA from this origin had an effect on the estrogenic activity of human saliva. Moreover, the fissure sealant DELTON $®$ showed significantly higher levels of BPA leaching [57].

This problem of the presence of BPA in the human body is a very serious question, especially in the USA where the National Toxicology Program (NTP) and its Center for the Evaluation of Risks to Human Reproduction (CERHR) (59) have attributed to the BPA problem the level some concern", corresponding to the intermediate value on a scale of 5 levels.

These results underscore the latent difficulties in accurately analyzing BPA levels in any complex mixture, such as dental resin extracts. In order to steer clear of incorrectly identifying the extractable substances and the ensuing inaccurate quantitative assignments for species of interest, good separation and suitable detection methods constitute the sine qua non prerequisites. Dependable methods are hence crucial for accurate valuation and appraisal of patient exposure to BPA and establishment of significant health risk assessments. In essence, this issue is still way from being fully grasped and resolved [60].

\section{Risk Evaluation}

The release of methacrylic monomers and polymerization compounds can lead to adverse biological responses inclusive of local and systemic toxicity, pulp reactions, and allergic and estrogenic effects [61].

Salivary esterases can lead to the degradation of TEGDMA and HEMA structures, and thus result in liposoluble metabolites that could build up in adipose tissues [62]. In addition, both TEGDMA and HEMA trigger oxidative stress and mitochondrial damage in odontoblast-like cells [63].

It is well recognized that the majority of dental composites release TEGDMA, both in vitro and in vivo, and that this compound is toxic. The direct biological risks consist of post-placement tooth sensitivity [64], apoptotic reactions [65], long-term pulpal inflammation [66], systemic estrogenic effects [67], and allergic reactions [68]. The latter is less well documented, yet widely discussed in the literature.

TEGDMA, on the other hand, exhibits mutagenic behavior [69]. Resin-based restorations usually leach components that have the potential of inducing DNA double-strand breaks (DSBs) and cell death effects, i.e. both apoptosis and necrosis, in human gingival fibroblasts (HGFs) [70].

Moreover, TEGDMA induced mitochondrial damage in HGFs [71] and mainly caused apoptosis [72].

The adverse biological effects of HEMA can lead to DNA damage, apoptosis, and cell-cycle delay [73]. In view of the bioavailability of HEMA and TEGDMA resin monomers, the findings suggest the need for additional in-depth investigations with re- 
spect to the local and systemic reactions of these compounds in vitro and in vivo. A close monitoring and careful indication of their use within the realm of odontology is highly recommended [74].

Resin composites are susceptible to hydrolysis through esterase activity prevalent in the oral cavity. Their biodegradation results in the deterioration of the bulk structure of resin composites as well as that of the composite-tooth interface and the release of degradation products such as methacrylic acid, triethylene glycol (TEG), and bishydroxy-propoxy-phenyl-propane (BisHPPP). It has been confirmed that all of the latter affect cariogenic bacterial growth and virulence, thus acting as major contributing factors in the incidence of recurrent caries, hypersensitivity, and pulpal inflammation [75].

TEG, the dental composite degradation product, may contribute to streptococcus mutans establishment in various cariogenic biofilms. These findings account for the higher failure rates due to the increased prevalence of secondary caries and an increased frequency of resin composite restoration replacement [76]. Most notably, the findings should stir and prompt the clinical community to take action towards having resin composite manufacturers exercise a greater diligence with regard to the biological description of their products and related degradation by-products as well as have them refrain from affirming to current materials as biologically inert dental materials [77]. Furthermore, a number of composite resins pose a threat to the health of patients and dental personnel. [78].

The risks for human health, namely allergies and cytotoxicity, are consequently substantial. In view of avoiding these characteristic risks, the introduction of newer materials constitutes a key component for subsequent research.

In their study, Kilambi et al. [79] proposed the replacement of TEGDMA in dental composite formulations by very reactive monovinyl methacrylates for the purpose of obtaining resins boasting the same, or even superior, composite polymer mechanical properties. A TEGDMA- free and HEMA-free composite resin has already been available on the market for several years, namely the "ELS Extra Low Shrinkage" resin by Saremco (Résine composite dentaire els Extra Low Shrinkage, Saremco Dental AG, Rohnacker, 9445 Rebstein, Switzerland). Its evaluation demonstrated favorable clinical behavior. Van Dijken and Palleson in 2017 [80] demonstrated that Class II restorations carried out with the TEGDMA/HEMA-free low shrinkage resin composite system showed good durability over six years. Several studies, including those of Reichl et al. [81], clearly demonstrate that this resin does not release TEGDMA or HEMA when compared to other composite resins available on the market today. For the purpose of eliminating the risk inherent in TEGDMA release, it would therefore be logical to conclude that the dental practitioner should aim at using TEGDMA-free and HEMA-free composites. The indication "some concern" attributed to the existence of BPA in the body in the statement of the American Dental Association (ADA) [82] puts this compound in a critical position and places it at the core of safety issues to be examined seriously. However, a 2017 analysis of BPA levels released from resin-based dental sealants shows that exposure from dental sealants is below the daily exposure level set by the US Environmental Protection Agency (EPA) and can thus be considered safe [83].
After mentioning that the products containing Bis-DMA could release small BPA amounts through biodegradation of the BisDMA molecule by salivary enzymes, it goes on to state verbatim, "Based on current research, the association agrees with the authoritative government agencies that the low-level of BPA exposure that may result from dental sealants and composites poses no known health threat". In the same document, the ADA further quotes the following statement of the U.S. Department of Health and Human Services (HHS): Dental sealant exposure to bisphenol A occurs primarily with use of dental sealants [containing] bisphenol A dimethacrylate. This exposure is considered an acute and infrequent event with little relevance to estimating general population exposures."

Hence, in the event BPA turns into a public health problem, it is more because of the manifold exposure possibilities in everyday life - particularly through applications using polycarbonates - than through the highly restricted use of dental sealants, among which only a few contain Bis- DMA, which is possibly susceptible to degrade into BPA.

On the other hand, a number of procedures and measures can reduce exposure to free monomers due to direct composite restorations, such as rubber dam use and prolonged curing (up to double the recommended time). Moreover, darker shade composites (C2) present higher cytotoxicity, which can be minimized by polymerization with the high-intensity light curing unit. Resin- composite cytotoxicity varies with shade and irradiance.

\section{Conclusion}

TEGDMA and BPA present possible risks to human health. The possibility of release of TEGDMA from composite resins is high, and the risk of allergies and cytotoxicity has been documented. The best protection measure consists of using composites without TEGDMA. With regard to BPA, even if it presents a potentially greater and more serious risk to health, particularly via its potential to affect the endocrine equilibrium, the probability of its availability from dental restorative materials is much lower. BPA is usually confined to dental sealants only, and its use is less frequent than that of dental composite resins. Here again, the best protection lies in simply circumventing the use of sealants containing Bis-DMA.

\section{References}

[1]. Opdam NJ, van de Sande FH, Bronkhorst E, Cenci MS, Bottenberg P, Pallesen U, et al. Longevity of posterior composite restorations: a systematic review and meta-analysis. J Dent Res. 2014 Oct;93(10):943-9. Pubmed PMID: 25048250.

[2]. Ferracane JL. Resin composite--state of the art. Dent Mater. 2011 Jan;27(1):29-38. Pubmed PMID: 21093034.

[3]. Geurtsen W. Substances released from dental resin composites and glass ionomer cements. Eur J Oral Sci. 1998 Apr;106(2 Pt 2):687-95. Pubmed PMID: 9584902.

[4]. Barrett ES, Sobolewski M. Polycystic ovary syndrome: do endocrine-disrupting chemicals play a role? Semin Reprod Med. 2014 May;32(3):16676. Pubmed PMID: 24715511.

[5]. Frye CA, Bo E, Calamandrei G, Calzà L, Dessì-Fulgheri F, Fernández M, et al. Endocrine disrupters: a review of some sources, effects, and mechanisms of actions on behaviour and neuroendocrine systems. J Neuroendocrinol. 2012 Jan;24(1):144-59. Pubmed PMID: 21951193.

[6]. Rochester JR. Bisphenol A and human health: a review of the literature. Reprod Toxicol. 2013 Dec;42:132-55. Pubmed PMID: 23994667. 
[7]. Olea N, Pulgar R, Pérez P, Olea-Serrano F, Rivas A, Novillo-Fertrell A, et al. Estrogenicity of resin-based composites and sealants used in dentistry. Environ Health Perspect. 1996 Mar;104(3):298-305. Pubmed PMID: 8919768.

[8]. Finer Y, Santerre JP. Salivary esterase activity and its association with the biodegradation of dental composites. J Dent Res. 2004 Jan;83(1):22-6. Pubmed PMID: 14691108.

[9]. Shokati B, Tam LE, Santerre JP, Finer Y. Effect of salivary esterase on the integrity and fracture toughness of the dentin-resin interface. J Biomed Mater Res B Appl Biomater. 2010 Jul;94(1):230-7. Pubmed PMID: 20524199.

[10]. Dursun E, Fron-Chabouis H, Attal JP, Raskin A. Bisphenol A Release: Survey of the Composition of Dental Composite Resins. Open Dent J. 2016 Aug 31;10:446-453. Pubmed PMID: 27708726.

[11]. Polydorou O. Elution of substances from dental composite materials. InDental Composite Materials for Direct Restorations 2018 (pp. 179-195). Springer, Cham.

[12]. Fadini L, Brambilla R, Cagetti MG, Gagliani M. G It Cons 2006, Suppl vol IV n. 1, January-March.

[13]. Polydorou O, König A, Hellwig E, Kümmerer K. Long-term release of monomers from modern dental-composite materials. Eur J Oral Sci. 2009 Feb;117(1):68-75. Pubmed PMID: 19196321.

[14]. Van Landuyt KL, Nawrot T, Geebelen B, De Munck J, Snauwaert J, Yoshihara $\mathrm{K}$, et al. How much do resin-based dental materials release? A metaanalytical approach. Dent Mater. 2011 Aug;27(8):723-47. Pubmed PMID: 21664675.

[15]. Michelsen VB, Kopperud HB, Lygre GB, Björkman L, Jensen E, Kleven IS, et al. Detection and quantification of monomers in unstimulated whole saliva after treatment with resin-based composite fillings in vivo. Eur J Oral Sci. 2012 Feb;120(1):89-95. Pubmed PMID: 22288926.

[16]. Sideridou ID, Achilias DS. Elution study of unreacted Bis-GMA, TEGDMA, UDMA, and Bis-EMA from light-cured dental resins and resin composites using HPLC. J Biomed Mater Res B Appl Biomater. 2005 Jul;74(1):617-26. Pubmed PMID: 15889433

[17]. Schmalz G, Preiss A, Arenholt-Bindslev D. Bisphenol-A content of resin monomers and related degradation products. Clin Oral Investig. 1999 Sep;3(3):114-9. Pubmed PMID: 10803121

[18]. Goldberg M. In vitro and in vivo studies on the toxicity of dental resin components: a review. Clin Oral Investig. 2008 Mar;12(1):1-8. Pubmed PMID: 18040729 .

[19]. Durner J, Spahl W, Zaspel J, Schweikl H, Hickel R, Reichl FX. Eluted substances from unpolymerized and polymerized dental restorative materials and their Nernst partition coefficient. Dent Mater. 2010 Jan;26(1):91-9. Pubmed PMID: 19781758.

[20]. Van Landuyt KL, Nawrot T, Geebelen B, De Munck J, Snauwaert J, Yoshihara $\mathrm{K}$, et al. How much do resin-based dental materials release? A metaanalytical approach. Dent Mater. 2011 Aug;27(8):723-47. Pubmed PMID: 21664675.

[21]. Manojlovic D, Radisic M, Vasiljevic T, Zivkovic S, Lausevic M, Miletic V. Monomer elution from nanohybrid and ormocer-based composites cured with different light sources. Dent Mater. 2011 Apr;27(4):371-8. Pubmed PMID: 21168907.

[22]. Putzeys E, Nys S, Cokic SM, Duca RC, Vanoirbeek J, Godderis L, et al. Long-term elution of monomers from resin-based dental composites. Dent Mater. 2019 Mar;35(3):477-485. Pubmed PMID: 30704750.

[23]. Tsitrou E, Kelogrigoris S, Koulaouzidou E, Antoniades-Halvatjoglou M, Koliniotou-Koumpia E, van Noort R. Effect of extraction media and storage time on the elution of monomers from four contemporary resin composite materials. Toxicol Int. 2014 Jan;21(1):89-95. Pubmed PMID: 24748741.

[24]. Rothmund L, Reichl FX, Hickel R, Styllou P, Styllou M, Kehe K, et al. Effect of layer thickness on the elution of bulk-fill composite components. Dent Mater. 2017 Jan;33(1):54-62. Pubmed PMID: 27836116.

[25]. Khalid H, Suhaib F, Zahid S, Ahmed S, Jamal A, Kaleem M, et al. Microwave-assisted synthesis and in vitro osteogenic analysis of novel bioactive glass fibers for biomedical and dental applications. Biomed Mater. 2018 Oct 31;14(1):015005. Pubmed PMID: 30251708

[26]. Yang Y, Reichl FX, Shi J, He X, Hickel R, Högg C. Cytotoxicity and DNA double-strand breaks in human gingival fibroblasts exposed to eluates of dental composites. Dent Mater. 2018 Feb;34(2):201-208. Pubmed PMID: 29042079.

[27]. Łagocka R, Mazurek-Mochol M, Jakubowska K, Bendyk-Szeffer M, Chlubek D, Buczkowska-Radlińska J. Analysis of Base Monomer Elution from 3 Flowable Bulk-Fill Composite Resins Using High Performance Liquid Chromatography (HPLC). Med Sci Monit. 2018 Jul 7;24:4679-4690. Pubmed PMID: 29980660.

[28]. Gezgin O, Korkut E, Tulumbacı F, Özer H, Sener Y. HPLC analysis of eluted monomers released from dental composites containing bioactive glass. Journal of adhesion science and Technology. 2018 Aug 3;32(15):1724-31.

[29]. Stanislawski L, Daniau X, Lauti A, Goldberg M. Factors responsible for pulp cell cytotoxicity induced by resin-modified glass ionomer cements. J Biomed Mater Res. 1999;48(3):277-88. Pubmed PMID: 10398031

[30]. Bouillaguet S, Virgillito M, Wataha J, Ciucchi B, Holz J. The influence of dentine permeability on cytotoxicity of four dentine bonding systems, in vitro. J Oral Rehabil. 1998 Jan;25(1):45-51. Pubmed PMID: 9502126.

[31]. Schmalz G. The biocompatibility of non-amalgam dental filling materials Eur J Oral Sci. 1998 Apr;106(2 Pt 2):696-706. Pubmed PMID: 9584903.

[32]. Gerzina TM, Hume WR. Diffusion of monomers from bonding resinresin composite combinations through dentine in vitro. J Dent. 1996 JanMar;24(1-2):125-8. Pubmed PMID: 8636483.

[33]. Reichl FX, Seiss M, Kleinsasser N, Kehe K, Kunzelmann KH, Thomas P, et al. Distribution and excretion of BisGMA in guinea pigs. J Dent Res. 2008 Apr;87(4):378-80. Pubmed PMID: 18362323.

[34]. Marquardt W, Seiss M, Hickel R, Reichl FX. Volatile methacrylates in dental practices. J Adhes Dent. 2009 Apr;11(2):101-7. Pubmed PMID 19492711.

[35]. Geurtsen W. Biocompatibility of resin-modified filling materials. Crit Rev Oral Biol Med. 2000;11(3):333-55. Pubmed PMID: 11021634.

[36]. Lee DH, Lim BS, Lee YK, Ahn SJ, Yang HC. Involvement of oxidative stress in mutagenicity and apoptosis caused by dental resin monomers in cell cultures. Dent Mater. 2006 Dec;22(12):1086-92. Pubmed PMID: 16376982.

[37]. Spagnuolo G, Galler K, Schmalz G, Cosentino C, Rengo S, Schweikl H. Inhibition of phosphatidylinositol 3-kinase amplifies TEGDMA-induced apoptosis in primary human pulp cells. J Dent Res. 2004 Sep;83(9):703-7. Pubmed PMID: 15329376.

[38]. About I, Camps J, Mitsiadis TA, Bottero MJ, Butler W, Franquin JC. Influence of resinous monomers on the differentiation in vitro of human pulp cells into odontoblasts. J Biomed Mater Res. 2002;63(4):418-23. Pubmed PMID: 12115750.

[39]. Durner J, Dębiak M, Bürkle A, Hickel R, Reichl FX. Induction of DNA strand breaks by dental composite components compared to X-ray exposure in human gingival fibroblasts. Arch Toxicol. 2011 Feb;85(2):143-8. Pubmed PMID: 20490463.

[40]. Urcan E, Scherthan H, Styllou M, Haertel U, Hickel R, Reichl FX. Induction of DNA double-strand breaks in primary gingival fibroblasts by exposure to dental resin composites. Biomaterials. 2010 Mar;31(8):2010-4. Pubmed PMID: 20004467.

[41]. Reichl FX, Durner J, Hickel R, Spahl W, Kehe K, Walther U, et al. Uptake, clearance and metabolism of TEGDMA in guinea pigs. Dent Mater. 2002 Dec;18(8):581-9. Pubmed PMID: 12385899.

[42]. Engelmann J, Leyhausen G, Leibfritz D, Geurtsen W. Metabolic effects of dental resin components in vitro detected by NMR spectroscopy. J Dent Res. 2001 Mar;80(3):869-75. Pubmed PMID: 11379887.

[43]. Schweikl H, Schmalz G. Triethylene glycol dimethacrylate induces large deletions in the hprt gene of V79 cells. Mutat Res. 1999 Jan 2;438(1):71-8. Pubmed PMID: 9858690.

[44]. Khalichi P, Singh J, Cvitkovitch DG, Santerre JP. The influence of triethylene glycol derived from dental composite resins on the regulation of Streptococcus mutans gene expression. Biomaterials. 2009 Feb;30(4):452-9. Pubmed PMID: 18990441.

[45]. Sadeghinejad L, Cvitkovitch DG, Siqueira WL, Merritt J, Santerre JP, Finer Y. Mechanistic, genomic and proteomic study on the effects of BisGMAderived biodegradation product on cariogenic bacteria. Dent Mater. 2017 Feb;33(2):175-190. Pubmed PMID: 27919444.

[46]. Sadeghinejad L, Cvitkovitch DG, Siqueira WL, Santerre JP, Finer Y. Triethylene Glycol Up-Regulates Virulence-Associated Genes and Proteins in Streptococcus mutans. PLoS One. 2016 Nov 7;11(11):e0165760. Pubmed PMID: 27820867.

[47]. Reichl FX. Toxicology and side effects of components from dental materials. InCED-IADR Annual Meeting, Munich 2009 Sep 10.

[48]. Jaoude SB, Naaman N, Nehme E, Gebeily J, Daou M. Hand eczema among Lebanese dentists: An epidemiological study. Dental and Medical Problems. 2017;54(4):397-401.

[49]. Seiss M, Track N, Hickel R, Reichl FX. In vitro stability of methylmethacrylic acid, TEGDMA and HEMA exposed to esterases. Dent Mater. 2009 Aug;25(8):1044-9. Pubmed PMID: 19361853.

[50]. Geurtsen- W, Leyhausen G. Chemical-Biological Interactions of the resin monomer triethyleneglycol-dimethacrylate (TEGDMA). J Dent Res. 2001 Dec;80(12):2046-50. Pubmed PMID: 11808759

[51]. Emmler J, Seiss M, Kreppel H, Reichl FX, Hickel R, Kehe K. Cytotoxicity of the dental composite component TEGDMA and selected metabolic byproducts in human pulmonary cells. Dent Mater. 2008 Dec;24(12):1670-5. Pubmed PMID: 18486204

[52]. Gregson KS, Terrence O'Neill J, Platt JA, Jack Windsor L. In vitro induction of hydrolytic activity in human gingival and pulp fibroblasts by triethylene glycol dimethacrylate and monocyte chemotatic protein-1. Dent Mater. 2008 Nov;24(11):1461-7. Pubmed PMID: 18439669. 
[53]. Imazato S, Horikawa D, Nishida M, Ebisu S. Effects of monomers eluted from dental resin restoratives on osteoblast-like cells. J Biomed Mater Res B Appl Biomater. 2009 Feb;88(2):378-86. Pubmed PMID: 18395824.

[54]. Tillett T. Bisphenol A, chapter 2: new data shed light on exposure, potential bioaccumulation. Environ Health Perspect. 2009 May;117(5):A210. Pubmed PMID: 19478989.

[55]. Furche S, Hickel R, Reichl FX, van Landuyt K, Shehata M, Durner J. Quantification of elutable substances from methacrylate based sealers and their cytotoxicity effect on with human gingival fibroblasts. Dent Mater. 2013 Jun;29(6):618-25. Pubmed PMID: 23570627.

[56]. Rochester JR, Bolden AL, Kwiatkowski CF. Prenatal exposure to bisphenol A and hyperactivity in children: a systematic review and meta-analysis. Environ Int. 2018 May;114:343-356. Pubmed PMID: 29525285.

[57]. Becher R, Wellendorf H, Sakhi AK, Samuelsen JT, Thomsen C, Bølling AK, et al. Presence and leaching of bisphenol a (BPA) from dental materials. Acta Biomater Odontol Scand. 2018 May 27;4(1):56-62. Pubmed PMID: 29868625.

[58]. Arenholt-Bindslev D, Breinholt V, Preiss A, Schmalz G. Time-related bisphenol-A content and estrogenic activity in saliva samples collected in relation to placement of fissure sealants. Clin Oral Investig. 1999 Sep;3(3):1205. Pubmed PMID: 10803122

[59]. Bucher JR. Bisphenol A: where to now? Environ Health Perspect. 2009 Mar;117(3):A96-7. Pubmed PMID: 19337497.

[60]. Hope E, Reed DR, Moilanen LH. Potential confounders of bisphenol-a analysis in dental materials. Dent Mater. 2016 Aug;32(8):961-7. Pubmed PMID: 27257102.

[61]. Bakopoulou A, Papadopoulos T, Garefis P. Molecular toxicology of substances released from resin-based dental restorative materials. Int J Mol Sci. 2009 Sep 4;10(9):3861-99. Pubmed PMID: 19865523.

[62]. Seiss M, Track N, Hickel R, Reichl FX. In vitro stability of methylmethacrylic acid, TEGDMA and HEMA exposed to esterases. Dent Mater. 2009 Aug;25(8):1044-9. Pubmed PMID: 19361853.

[63]. Baldion P et al .Oxydative stress induced by dental monomers in human odontoblast -like cells. 2017.

[64]. Unemori M, Matsuya Y, Akashi A, Goto Y, Akamine A. Composite resin restoration and postoperative sensitivity: clinical follow-up in an undergraduate program. J Dent. 2001 Jan;29(1):7-13. Pubmed PMID: 11137633.

[65]. Goldberg M, Lasfargues JJ, Legrand JM. Clinical testing of dental materials--histological considerations. J Dent. 1994;22 Suppl 2:S25-8. Pubmed PMID: 7844272.

[66]. Hebling J, Giro EM, Costa CA. Biocompatibility of an adhesive system applied to exposed human dental pulp. J Endod. 1999 Oct;25(10):676-82. Pubmed PMID: 10687527.

[67]. Schafer TE, Lapp CA, Hanes CM, Lewis JB, Wataha JC, Schuster GS. Estrogenicity of bisphenol A and bisphenol A dimethacrylate in vitro. J Biomed Mater Res. 1999 Jun 5;45(3):192-7. Pubmed PMID: 10397975.

[68]. Katsuno K, Manabe A, Itoh K, Nakamura Y, Wakumoto S, Hisamitsu H, et al. Contact dermatitis caused by 2-HEMA and GM dentin primer solutions applied to guinea pigs and humans. Dent Mater J. 1996 Jun;15(1):22-30. Pubmed PMID: 8940535.
[69]. Schweikl H, Schmalz G, Rackebrandt K. The mutagenic activity of unpolymerized resin monomers in Salmonella typhimurium and V79 cells. Mutat Res. 1998 Jul 8;415(1-2):119-30. Pubmed PMID: 9711268.

[70]. Shehata M, Durner J, Eldenez A, Van Landuyt K, Styllou P, Rothmund L, et al. Cytotoxicity and induction of DNA double-strand breaks by components leached from dental composites in primary human gingival fibroblasts. Dent Mater. 2013 Sep;29(9):971-9. Pubmed PMID: 23915819.

[71]. Lefeuvre M, Amjaad W, Goldberg M, Stanislawski L. TEGDMA induces mitochondrial damage and oxidative stress in human gingival fibroblasts. Biomaterials. 2005 Sep;26(25):5130-7. Pubmed PMID: 15792539.

[72]. Reichl FX, Esters M, Simon S, Seiss M, Kehe K, Kleinsasser N, et al. Cell death effects of resin-based dental material compounds and mercurials in human gingival fibroblasts. Arch Toxicol. 2006 Jun;80(6):370-7. Pubmed PMID: 16691427.

[73]. Pawlowska E, Poplawski T, Ksiazek D, Szczepanska J, Blasiak J. Genotoxicity and cytotoxicity of 2-hydroxyethyl methacrylate. Mutat Res. 2010 Feb;696(2):122-9. Pubmed PMID: 20079459.

[74]. Ginzkey C, Zinnitsch S, Steussloff G, Koehler C, Hackenberg S, Hagen $\mathrm{R}$, et al. Assessment of HEMA and TEGDMA induced DNA damage by multiple genotoxicological endpoints in human lymphocytes. Dent Mater. 2015 Aug;31(8):865-76. Pubmed PMID: 26025483.

[75]. Bourbia M, Finer Y. Biochemical Stability and Interactions of Dental Resin Composites and Adhesives with Host and Bacteria in the Oral Cavity: A Review. J Can Dent Assoc. 2018 Jan;84:i1. Pubmed PMID: 29513214.

[76]. Spencer P, Ye Q, Misra A, Goncalves SE, Laurence JS. Proteins, pathogens, and failure at the composite-tooth interface. J Dent Res. 2014 Dec;93(12):1243-9. Pubmed PMID: 25190266.

[77]. Sadeghinejad L, Cvitkovitch DG, Siqueira WL, Merritt J, Santerre JP, Finer Y. Mechanistic, genomic and proteomic study on the effects of BisGMAderived biodegradation product on cariogenic bacteria. Dent Mater. 2017 Feb;33(2):175-190. Pubmed PMID: 27919444.

[78]. Arossi GA, Dihl RR, Lehmann M, Reguly ML, de Andrade HH. Genetic toxicology of dental composite resin extracts in somatic cells in vivo. Basic Clin Pharmacol Toxicol. 2010 Jul;107(1):625-9. Pubmed PMID: 20210791.

[79]. Kilambi H, Cramer NB, Schneidewind LH, Shah P, Stansbury JW, Bowman $\mathrm{CN}$. Evaluation of highly reactive mono-methacrylates as reactive diluents for BisGMA-based dental composites. Dent Mater. 2009 Jan;25(1):338. Pubmed PMID: 18584862.

[80]. van Dijken JWV, Pallesen U. Durability of a low shrinkage TEGDMA/ HEMA-free resin composite system in Class II restorations. A 6-year follow up. Dent Mater. 2017 Aug;33(8):944-953. Pubmed PMID: 28545657.

[81]. Reichl FX, Seiss M, Oxynos A, Folwaczny M, Glas J, Kehe K, et al. Qualitative and quantitative analysis of eluted compounds from dental composites. InCED-IADR Annual Meeting, Thessaloniki 2007 Sep 26.

[82]. American Dental Association. ADA Positions and statements: Bisphenol A and Dental Materials.

[83]. Vinh R. Analysis of Bisphenol A Released From Resin-Based Dental Sealants. 2017 IADR General Session, March 2017. ID 2612 